\title{
Compatibility of Climate Adaptation Strategies with Livelihood Vulnerability Patterns: The Case of Fars Province, Iran
}

\section{Samane Ghazali}

Shiraz University School of Agriculture

Hossein Azadi ( $\sim$ hossein.azadi@ugent.be )

Ghent University https://orcid.org/0000-0002-5108-1993

Mansoor Zibaei

Shiraz University School of Agriculture

\section{Research Article}

Keywords: Adaptive capacity, Climate change, Data mining, Degraded rangelands, Pastoral livelihood

Posted Date: July 12th, 2021

DOl: https://doi.org/10.21203/rs.3.rs-674373/v1

License: (c) (1) This work is licensed under a Creative Commons Attribution 4.0 International License.

Read Full License 


\section{Abstract}

Pastoralists' livelihood on natural rangelands are constantly influenced by the destructive impacts of climate change. While the phenomenon of climate change continues on a widespread scale, it is expected to put more pressure on unfavorable rangelands and pastoral households whose livelihood source is only based on pastoralism activity. Thus, it is vital to reduce livelihood vulnerability of pastoralists to climate change impacts through appropriate adaptation strategies. Accordingly, the aim of the current study was to specify the compatibility of adaptation strategies adopted by pastoralists with their livelihood vulnerability patterns. The evaluation was based on a spatial survey that was conducted with a random sample of 393 Iranian pastoralists distributed in the counties of Eghlid, Sepidan, and Shiraz in the northern Fars province. The results showed that pastoralists were commonly vulnerable in terms of the high-risk exposure and low adaptive capacity. About 27 livelihood vulnerability patterns were detected using data mining based on the relationships among the sub-components of exposure, sensitivity, and adaptation in 3 counties. The scores of the livelihood vulnerability were high in most of the livelihood vulnerability patterns. Only 4 patterns obtained the relatively low vulnerability scores through accurate decisions on adopting the appropriate set of adaptation strategies. According to the low compatibility of adaptation strategies with the corresponding vulnerability patterns, the results of this study can assist pastoralists to adopt appropriate adaptation strategies and thus, decrease livelihood vulnerability to climate change. In this regard, it is suggested that pastoralists in each vulnerability pattern adopt appropriate adaptation strategies according to their vulnerability sub-components.

\section{Introduction}

Climate change is one of the major challenges facing the global community, which raises a great deal of concern (Bogaerts et al., 2017; Carolan, 2019; Ojo et al., 2021). Climate change affects environmental ecosystems, such as natural rangeland ecosystems, reduces forage production, changes rangeland quality, erodes soils, and causes the extinction of animal and plant species (Wüst-Galley et al., 2020). In addition, the revenue from traditional livelihood based on agriculture and pastoralism activities has recently declined due to climate change and degraded environmental ecosystem (McMillen et al., 2017). Another issue is that the unfavorable environment as a result of human activities is recognized as one of the major causes of climate change. For example, overgrazing on natural rangelands causes widespread degraded rangelands, and degraded rangelands lead to natural phenomena, including untimely floods (Nandintsetseg et al., 2018).

Multitude of pastoralists have suffered great damage due to endangering their pastoral livelihood against the natural phenomena, such as drought, untimely floods, and the degradation of natural rangelands (Chatrchyan et al., 2017; Neibergs et al., 2018). Low-income pastoralists are more vulnerable to climate change according to Intergovernmental Panel on Climate Change (IPCC) (Kogo et al., 2020). Researchers have considered livelihood vulnerability to climate change as a function of 3 components: risk exposure, sensitivity, and adaptive capacity (Amos et al., 2014; Hahn et al., 2009; Jamshidi et al., 2019; Omerkhil et al., 2020). The risk exposure indicates how much a household or community is at risk from natural 
phenomena (Amos et al., 2014; Hahn et al., 2009; Hamidi et al., 2020). The sensitivity is the degree to which a household or community is affected by natural phenomena (Amos et al., 2014; Endalew and Sen, 2020; Hahn et al., 2009). Due to the dependence of traditional pastoral livelihood on climatic situation and rangeland ecosystems, in recent years the sensitivity of pastoralists to climate change has increased. In such a way that natural phenomena have reduced pastoralists' livelihood sources. Adaptive capacity refers to the ability of a household or community to cope with and recover from the effects of climate change (Amos et al., 2014; Hahn et al., 2009; Ojo and Baiyegunhi, 2020; Thathsarani and Gunaratne, 2018). In contrast to livelihood vulnerability concept, adaptation strategy aims to raise community resilience to climate change. It is a framework to manage future climate risks, and to prioritize measures (Setten and Lein, 2019). Accordingly, pastoralists' adaptation strategies for climate variability comprise primarily livestock and rangeland management interventions, such as "purchasing fodder", "reducing livestock", "part-time grazing", and "renting rangelands" (Zhang et al., 2019).

A group of researchers has calculated vulnerabilities to drought due to climate change for traditional livelihoods based on agriculture and pastoralism in different countries (Adu et al., 2018; Dendir and Simane, 2019; Jamshidi et al., 2019; Karimi et al., 2018; Keshavarz et al., 2017). Adu et al. (2018) evaluated the vulnerability of farming households to climate change using the livelihood vulnerability index with specific emphasis on water resources in Ghana. Their results showed that farming households in the study area were differently vulnerable to climate change and weather variability in terms of vulnerability components. Thus, they explained the consequences of performing state plans to adapt farmers to climate change in the region. Dendir and Simane (2019) examined the livelihood vulnerability of farm households to climate variability and change in Gurage zone, Ethiopia by livelihood vulnerability index approaches. Their results indicated that although there was a difference in vulnerability components score across various areas, the overall index showed that the lowland region was more vulnerable to climate variability and change. They asked for officials to take specific steps to decrease farmers' vulnerability to climate change. In addition, Jamshidi et al. (2019) investigated the perceptions of farmers towards climate change, natural phenomena, and the factors contributing to livelihood vulnerability in 6 counties of Hamadan province, Iran. They incorporated various indicators for measuring 3 components of livelihood vulnerability: risk exposure, sensitivity, and adaptive capacity. Their survey reported that climate change was perceived by most farmers at the high level and they recognized this phenomenon as a result of human activities. Also, the livelihood vulnerability of majority of farmers was relatively high to climate change. In another similar study by Karimi et al. (2018), they found 3 patterns of livelihood vulnerability for herder households in Mamasani County, Iran. Furthermore, they identified the main adaptation strategies adopted by the herders of this region. Some adaptation strategies including forage purchase, grazing rotation, herd composition, and post-harvest grazing have been adopted by a large number of herders. Keshavarz et al. (2017) investigated the livelihood vulnerability of farm families to drought in Fars province, Iran. Their results showed that drought was the most important threat to livelihood security. In addition, 3 patterns of livelihood vulnerability were grouped as low, medium, and high, and in each pattern, farm families adopted different adaptation strategies. 
There are some shortcomings in previous vulnerability assessment studies e.g., Karimi et al. (2018), and Keshavarz et al. (2017) as follows: 1) the relationships among the sub-components of livelihood vulnerability have been ignored in determining livelihood vulnerability patterns, while considering those sub-components can provide more accurate patterns, 2) the compatibility of adaptation strategies with livelihood vulnerability patterns had not been investigated. To fill such gaps, the novelty of the current study is to detect vulnerability patterns in the form of association relations among the sub-components of livelihood vulnerability using data mining. Also, according to the interlinks among the sub-components in each vulnerability pattern, the compatibility of adaptation strategies adopted by pastoralists was specified to reduce the livelihood vulnerability.

Given the challenges of climate change, degraded rangelands, and vulnerability of pastoral livelihood, it is necessary to implement an appropriate set of adaptation strategies to adapt to climate change and diminish the livelihood vulnerability of Iranian pastoralists. To successfully implement such adaptation strategies, all pastoralists must have a correct understanding of their risks and vulnerabilities to climate change. Therefore, the main aim of the current study is to investigate the compatibility of pastoralists' adaptation decisions with their livelihood vulnerability patterns in the northern rangelands of Fars province in Iran. To this end, this study attempts to answer the following research questions as well:

- How is pastoralists' livelihood vulnerability to climate change in the northern Fars province?

- What patterns are detected for livelihood vulnerability using data mining?

- To what extent are pastoralists compatible with livelihood vulnerability patterns through adopting appropriate adaptation strategies?

\section{Methods}

\subsection{Survey area}

The current study was conducted in the rangelands of 3 counties of Eghlid, Sepidan, and Shiraz located in Fars province, Iran (Fig. 1). The study rangelands are located in the northern zones of Fars province which is the pole of rangeland in Iran. Despite the drought caused by climate change, Fars province is the first meat producer in the country with a production of more than 60 thousand tons (Agricultural Jihad Organization, 2018). Eghlid has an eastern longitude of $52^{\circ} 41^{\prime} 12^{\prime \prime} \mathrm{E}$ and a northern latitude of $30^{\circ} 53^{\prime}$ $56 " \mathrm{~N}$ that is located in an altitude of 2,250 meters from sea level. This county has the extent of 7,054 $\mathrm{Km}^{2}$ and the population of 90,869 (Statistical Center of Iran, 2016). The climate of Eghlid is cold and semi-arid (Keshavarz and Karami, 2016) and the quality of rangelands has recently decreased due to climatic reasons (Omidvar and Mohtasham Nia, 2015). Sepidan that is located in an eastern longitude of $52^{\circ} 27^{\prime} 62^{\prime \prime} \mathrm{E}$ and a northern latitude of $30^{\circ} 04^{\prime} 51^{\prime \prime} \mathrm{N}$ has an altitude of 2,650 meters above sea level. The county with the expanse of 2,846 $\mathrm{Km}^{2}$ has the population of 51,166 (Statistical Center of Iran, 2016). Sepidan climate is cold and humid (Keshavarz and Karami, 2016) and has the largest number of pastoralists (2,147 pastoralists) in Fars province due to the relatively suitable rangelands (Khodahami 
and Zandi Esfahan, 2015). Shiraz with an eastern longitude of $52^{\circ} 31^{\prime} 52.07^{\prime \prime} \mathrm{E}$ and a northern latitude of $29^{\circ} 36^{\prime} 37.12^{\prime \prime} \mathrm{N}$ has an altitude of 1,582 meters from sea level. Shiraz county which is the capital of Fars province has the area of $6,049 \mathrm{Km}^{2}$ and the population of 1,869,001 (Statistical Center of Iran, 2016). The climate of Shiraz county is temperate and semi-arid (Keshavarz and Karami, 2016) and excessive pastoralism has led to degraded rangelands in the region (Habibyian and Barani, 2019).

The sum of annual precipitation and the average temperature of counties were illustrated in Fig. 2. Over a period of more than 10 years, the sum of annual precipitation in the counties decreased and the average temperature in those areas increased (Meteorological Organization, 2020).

\subsection{Sampling, and designing questionnaire}

Using multiple stage cluster sampling method, we firstly selected sample villages then sample pastoralists were randomly selected. The formula of the sampling method is available in statistical text books such as Scheaffer et al. (2012). In this regard, the sampling procedure was implemented in 2 stages as follows: 1) selecting 5, 15, and 4 sample villages in the counties of Eghlid, Sepidan, and Shiraz, respectively, and 2 ) selecting 168,149 , and 76 sample pastoralists from selected villages.

The main instrument of data collection was questionnaire that was designed in a semi-structured way (Amos et al., 2014; Dang et al., 2014; Grothmann and Patt, 2005; Karimi et al., 2018). Face to face interviews with the total of 393 pastoralists of Fars province were conducted in 2018.

The questionnaire was designed for gathering the required data in 4 main components, including risk exposure, sensitivity, adaptive capacity, and adaptation strategies (Table 1). In the risk exposure component, it was examined to what extent pastoralists' revenue has been affected by climate change and degraded rangelands (Amos et al., 2014; Karimi et al., 2018). The sensitivity component actually surveyed the sensitivity of households and rangelands in terms of health, nutrition, and ecology to external stresses (Amos et al., 2014; Karimi et al., 2018). In the adaptive capacity component, it was investigated to what extent households have had necessary resources to engage in other income earning activities in addition to pastoralism (Dang et al., 2014; Grothmann and Patt, 2005; Karimi et al., 2018). Finally, the adaptation strategies component assessed the set of measures performed by households to adapt to climate change. In all the components of the questionnaire, respondents were asked to answer the questions taking into account the conditions of the last 10 years. Also, the considered subcomponents were ordinal and each one was arrayed based on 7 point Likert scales from 1 (not at all) to 7 (totally). The face validity of the questionnaire was confirmed by the faculty members of Shiraz University. Cronbachs' alpha coefficients for all the sub-components were more than 0.7 , which confirmed the reliability of the scales used in the current study.

\subsection{Evaluating livelihood vulnerability to climate change}

To evaluate pastoralists' livelihood vulnerability to climate change, the following 2 steps were followed:

1) determining the weight of the sub-components using principal component analysis, and 2) generating the livelihood vulnerability index based on weighted averaging. 
Using the principal component analysis, the weights were calculated for the sub-components of the main components, including risk exposure, sensitivity, and adaptive capacity. The analysis applied for this weighing is adopted from Karimi et al. (2018). The principal component analysis is a multivariate method that considers the maximum observed variance of the explanatory variables using the least possible number of components (Hair et al., 2010). The principal component analysis was performed using IBM SPSS Modeler version 18.0. Table 2 indicates the weights of the sub-components. The obtained weights for almost all the sub-components indicate that the considered sub-components mostly contribute to their corresponding components. The explained variation for risk exposure, sensitivity, and adaptive capacity was calculated $0.71,0.57$, and 0.63 .

After determining the weight of the sub-components, the 3 main components were calculated by weighted averaging (Eq. 1):

$$
\begin{aligned}
& \text { Risk exposure }_{i}=\left(\frac{\sum_{j=1}^{2} w_{j} \text { Exposure }_{i j}}{\sum_{j=1}^{2} w_{j}}\right) \\
& \text { Sensitivity }_{i}=\left(\frac{\sum_{j=1}^{3} w_{j} \text { Sensitivity }_{i j}}{\sum_{j=1}^{3} w_{j}}\right) \\
& \text { Adaptive capacity }_{i}=\left(\frac{\sum_{j=1}^{3} w_{j} \text { Adaptation }_{i j}}{\sum_{j=1}^{3} w_{j}}\right)
\end{aligned}
$$

Accordingly, i, j, and w indicate pastoralists, sub-component, and weight, respectively. After estimating risk exposure, sensitivity, and adaptive capacity of each pastoralist, the integrated index was applied for evaluating pastoralists' livelihood vulnerability to climate change (Amos et al., 2014; Hahn et al., 2009). In this regard, the definition of the livelihood vulnerability applied by IPCC was used through Eq. 2.

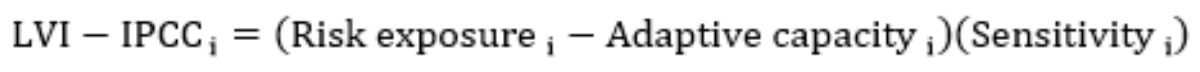

\subsection{Detecting livelihood vulnerability patterns}

To detect livelihood vulnerability patterns, data mining process was used. The process aims at finding valid, useful, novel and understandable patterns in database (Rashid et al., 2017). Accordingly, Cross Industrial Standard Process for Data Mining (CRISP-DM) that is the most widely-used analytics model was implemented in 6 steps as follows: 1) problem understanding in the form of detecting livelihood vulnerability patterns applying the sub-components, 2) data understanding in terms of acceptable range, missing data, outliers, and data consistency, 3) data preparation in the form of converting to binary data for association rules model, 4) modeling in the form of association rules to specify the relations among the considered sub-components, 5) evaluation in the form of adjusting results to address the detection of livelihood vulnerability patterns, 6 ) deployment in the form of offering patterns to policy makers to reduce pastoralists' livelihood vulnerability to climate change. 
Table 3 indicates the second step of the CRISP-DM. For all the sub-components, acceptable ranges of data were specified from 1 to 7 according to 7 Likert scales. No missing data and outlier were observed for the sub-components. But in terms of data consistency, adaptation sub-components was not aligned with 2 groups of exposure and sensitivity sub-components. Therefore, the inconsistency issue has been addressed in the data preparation step. For adaptation sub-components, the values in the range of $[5,7]$ were converted to 0 , and the values in the range of $[1,4]$ were converted to 1 in the third step of the CRISPDM. Conversely, for 2 groups of exposure and sensitivity sub-components, the values in the range of $[4,7]$ were converted to 1 , and the values in the range of $[1,3]$ were converted to 0 . In the fourth step of the CRISP-DM, Apriori algorithm was used for frequent sub-component set mining and association rule solving on livelihood vulnerability database. The algorithm proceeds by identifying the frequent individual sub-components in the database and extending them to larger and larger livelihood vulnerability subcomponents as long as those sub-component sets appear sufficiently often in the database. In this regard, suitable patterns have been considered and their support criterion was more than 10 households and their confidence criterion was $100 \%$. The data mining was performed using IBM SPSS Modeler version 18.0 .

\subsection{Analyzing the compatibility of adaptation strategies with livelihood vulnerability patterns}

To analyze adaptation strategies adopted by pastoralists, the distribution of pastoralists was performed based on their adaptation strategies (Karimi et al., 2018; Zorom et al., 2013). Also, in each livelihood vulnerability pattern, a set of adaptation strategies that were adopted by Iranian pastoralists was arranged. Comparing the score of the LVI-IPCC in each livelihood vulnerability pattern with the LVI-IPCC of each county, it was specified to what extent the adoption of those adaptation strategies was appropriate. It means that the compatibility of adaptation strategies adopted by Iranian pastoralists with livelihood vulnerability patterns was evaluated.

\section{Results}

\subsection{Pastoralists' livelihood vulnerability to climate change}

Table 4 shows the scores of pastoralists' livelihood vulnerability to climate change. The score of the risk exposure was6.92, 5.65, and 5.60 in 3 counties of Eghlid, Sepidan, and Shiraz, respectively. Therefore, pastoralists' revenue in Eghlid has been more affected by the threat of climate change and degraded rangelands. The scores of the sensitivity were computed for Eghlid, Sepidan, and Shiraz at 2.45, 1.83, and 2.26, respectively. According to the scores of the sub-components, the ecological sensitivity of rangelands in Eghlid (4.70) and Shiraz (3.97) was higher than Sepidan (1.64). Therefore, the occurrence of natural phenomena has caused more damage to rangelands' ecology in Eghlid and Shiraz. However, in terms of the nutritional sensitivity of households, Sepidan (2.68) was more sensitive than Eghlid (1.92) and Shiraz (2.17). The households' nutrition in Sepidan compared to Eghlid and Shiraz has been more dependent on traditional pastoralism. Also, the scores of the adaptive capacity for Eghlid, Sepidan, and Shiraz were 
$2.22,1.52$, and 2.17, respectively. According to the adaptive capacity in terms of time, households' adaptation was lower in Sepidan (1.81) compared to Eghlid (2.74), and Shiraz (2.81). Households have had less time to engage in other income earning activities in Sepidan. In addition, the scores of the budget adaptation were computed for Eghlid, Sepidan, and Shiraz at 1.32, 1.07, and 1.24, respectively. Thus, households have not had enough cash capital to engage in other income earning activities in 3 counties. Also, the adaptive capacity score in terms of skill was 1.59, 1.11, and 1.18 in 3 counties of Eghlid, Sepidan, and Shiraz, respectively. Thus, households have not had high skills to engage in other income earning activities. The LVI-IPCC of Eghlid (11.51) was higher than Sepidan (7.56) and Shiraz (7.75), because of the higher scores for the risk exposure and sensitivity.

\subsection{Livelihood vulnerability patterns}

Figure 3 demonstrates association rules of the relations among the livelihood vulnerability subcomponents due to 3 counties. In Eghlid county, more than $95 \%$ of households were vulnerable in terms of climate exposure, rangeland exposure, ecology sensitivity, and budget adaptation. Among the livelihood vulnerability sub-components, the highest frequency was detected for 3 sub-components of climate exposure, budget adaptation, and skill adaptation with above $95 \%$ of households in Sepidan. Also, more than $95 \%$ of households were vulnerable in terms of climate exposure, rangeland exposure, ecology sensitivity, and skill adaptation in Shiraz.

The outcomes of the Apriori algorithm indicate the existing separate patterns of livelihood vulnerability in the counties of Eghlid (10 vulnerability patterns), Sepidan, (9 vulnerability patterns) and Shiraz (8 vulnerability patterns) (see Table 5 , the third column). For example, the $1 \mathrm{st}$ pattern of livelihood vulnerability shows that there was a relationship between "climate exposure" and "rangeland exposure". In other words, the 1st pattern indicates that the high frequency of occurrence of "climate exposure" and "rangeland exposure" caused the livelihood vulnerability for pastoralists in Eghlid county. The LVI-IPCC score of the 1st pattern was also calculated in the relatively high level (11.61) while the corresponding value for Eghlid was lower (11.51). Similarly, the livelihood vulnerability status of other patterns can be interpreted.

\subsection{Compatibility of adaptation strategies with livelihood vulnerability patterns}

Adaptation strategies adopted by pastoralists under the changing climate are illustrated in Fig. 4. The priority adaptation strategies in Eghlid county included health, nutrition, and herd size, which were adopted by $85 \%, 82 \%$, and $72 \%$ of households, respectively. In Sepidan, $90 \%$ of pastoralists reduced their herd size to adapt to climate change. Next, adaptation strategies of nutrition and health were adopted by $78 \%$ and $75 \%$ of households, respectively. The most common adaptation strategies in Shiraz included herd size, nutrition, and fodder, which were adopted by $92 \%, 86 \%$, and $74 \%$ of households, respectively. In contrast, a few numbers of households participated in skill course of learning handicraft, apiculture, and fish farming (20\% in Eghlid, $9 \%$ in Sepidan, $16 \%$ in Shiraz), insured their herds (10\% in Eghlid, $23 \%$ in 
Sepidan, $13 \%$ in Shiraz), or received credits from banks and financial institutions ( $22 \%$ in Eghlid, $12 \%$ in Sepidan, $19 \%$ in Shiraz).

Table 5 shows the compatibility of adaptation strategies adopted by pastoralists with livelihood vulnerability patterns. Comparing adaptation strategies with livelihood vulnerability patterns shows that pastoralists have only adopted an appropriate set of adaptation strategies in 4 patterns $(4,14,15$, and 21). Households in the 4th pattern were vulnerable due to the relationship between "rangeland exposure" and "skill adaptation". Accordingly, pastoral households have been able to reduce "rangeland exposure" by adopting a diversification strategy to diversify income earning activities, and increase "skill adaptation" by participating in skill course of learning handicraft, apiculture, and fish farming. In pattern 14 , the relationship was detected between "rangeland exposure" and "budget adaptation". The set of adaptation strategies have also included diversification, evacuation, credit, which were perfectly able to reduce the livelihood vulnerability of this pattern. Pastoral households were vulnerable due to the relation between "rangeland exposure" and "skill adaptation", in pattern 15. Thus, pastoralists decreased their vulnerability by reducing their herd size, diversifying their revenue source with various income earning activities, and participating in skill courses of learning other activities. Finally, pastoralists were vulnerable due to the relation between "rangeland exposure" and "budget adaptation" in pattern 21. Households reduced "rangeland exposure" by evacuating rangelands and engaging in various income earning activities, and increased "budget adaptation" by receiving credits.

\section{Discussion}

\subsection{Livelihood vulnerability to climate change in the northern Fars province}

The findings of calculating the livelihood vulnerability of Iranian pastoralists to climate change show that households in Eghlid (11.51) were the most vulnerable based on the LVIIIPCC score. The reason of the high livelihood vulnerability of pastoralists in the county was that their revenue has been strongly affected by climate change (6.92) and degraded rangelands (6.90). During the last 10 years, climatic variables such as reduced rainfall, occurrence of natural phenomena such as frost, and degraded rangelands in the form of reduced forage quality have been more tangible in Eghlid county. The second reason for the high livelihood vulnerability of pastoralists in Eghlid was the high ecological sensitivity of their rangelands (4.70). Since, their rangelands' ecology has been severely affected by natural phenomena such as frost and untimely floods. In addition to the mentioned reasons, the adaptive capacity in terms of cash (1.32) was at a low level in the county. This means that households did not have enough cash to engage in other income earning activities.

In Shiraz, the score of LVIIIPCC (7.75) was relatively moderate. The main reason for the livelihood vulnerability of pastoralists in this county was the risk exposure (5.60) of their revenue from external stresses such as climate change and degraded rangelands. Also, the ecological sensitivity of rangelands (3.97) to natural phenomena was relatively high. The major natural phenomenon that has recently been 
observed in Shiraz has been the occurrence of spring floods. The third reason for the livelihood vulnerability of pastoralists in this county was explored that their households have low skills (1.18) for engaging in various income earning activities.

The lowest livelihood vulnerability to climate change based on the LVI-IPCC score was obtained in Sepidan county (7.56). The first reason for livelihood vulnerability in this county was the occurrence of climate change in the form of reduced rainfall and dried springs and its effect on pastoralists' revenue (5.64), and the degradation of natural rangelands and its effect on pastoral livelihood (5.75). The second reason for livelihood vulnerability in Sepidan was the nutritional sensitivity of households (2.68). Pastoralists' livelihood in this county has highly relied on traditional pastoralism, and it has been the main source of households' nutrition. In addition to those reasons, households' adaptive capacity in terms of cash (1.07) and skills (1.11) to engage in other income earning activities was very low.

Various scholars such as Adu et al. (2018), Gerlitz et al. (2016), Panthi et al. (2015), and Toufique and Islam (2014), examined livelihood vulnerabilities with respect to 3 components of risk exposure, sensitivity, and adaptive capacity and their results confirm the findings of the current study. The vulnerability studies of Nabua et al. (2010) on indigenous individuals in Philippines and Panthi et al. (2015) on pastoralists in the central Nepal showed that nutrition security, health conditions, and health services were important components in terms of sensitivity component. The nutrition insecurity, and unfavorable health conditions had led to high livelihood vulnerability to climate change. Also, Ashok and Sasikala (2012), Biazin and Sterk (2013), Gerlitz et al. (2016), Sietz et al. (2011), and Toufique and Islam (2014) showed that livelihoods based on traditional agriculture and pastoralism had increased the risk exposure and the livelihood vulnerability to climate change. In contrast, several researchers, such as Adu et al. (2018), Antuwi- Agyei et al. (2013), Biazin and Sterk (2013), and Morzaria-Luna et al. (2014) discussed that households that did not rely on one activity and diversified their livelihoods were able to adapt to external stresses. Therefore, they reduced their livelihood vulnerability to climate change and were resilient.

\subsection{Livelihood vulnerability patterns according to data mining}

Using data mining, 27 livelihood vulnerability patterns based on the relationship among 9 subcomponents were detected for 3 counties. In Eghlid county, the number of 10 separate patterns were extracted. The 1st livelihood vulnerability pattern shows that pastoralists were vulnerable due to high climate exposure and rangeland exposure. According to the 2nd to 8th pattern, pastoral households were vulnerable due to high exposure and low adaptation in their different sub-components. Also, the 9th and 10th patterns of livelihood vulnerability indicate the relations among high exposure, high sensitivity, and low adaptation in their different sub-components. In Sepidan, 9 separate patterns of livelihood vulnerability were obtained. Pastoral households of the county were vulnerable due to the various relationship among exposure and adaptation. While the 1 st livelihood vulnerability pattern of the county was detected due to the relationship among the exposure sub-components, other livelihood vulnerability 
patterns were extracted from the relationship among the sub-components of exposure and adaptation. Also, 8 separate patterns were also detected in Shiraz. In the 1st livelihood vulnerability pattern of the county, pastoralists were only vulnerable due to high exposure in terms of climate change and degraded rangeland. Pastoral households were vulnerable to climate change due to high exposure and low adaptation in 5 livelihood vulnerability patterns. In the last 2 patterns, livelihood vulnerability was detected due to high exposure, high sensitivity, and low adaptation in their different sub-components.

The results of other researchers such as Karimi et al. (2018), Kok et al. (2015), and Pandey and Bardsley (2015) on vulnerability patterns were clustered in different vulnerability levels (low, medium, and high). Karimi et al. (2018) discovered low, medium, and high vulnerability patterns of livestock keepers in southwest Iran, which were principally extracted by cluster analyzing on risk exposure, sensitivity, and adaptive capacity. According to their results, the high vulnerability pattern had a high score in the components of risk exposure and sensitivity, and a low score in the component of adaptive capacity. The clusters that were detected by Kok et al. (2015) were labeled as vulnerability profiles. Those profiles reported different typical groupings of conditions and processes that caused vulnerability of farmers in drylands. Their results incorporated 8 separate vulnerability profiles in the study area. The analysis of vulnerability profiles was used as a base to identify reactions to reduce vulnerability. The study findings of Pandey and Bardsley (2015) revealed significant levels of risk exposure to climate change and sensitivity to extreme weather events, but low adaptive capacities to adapt to climate change resulted in very high vulnerability. However, there were variations in the vulnerability levels among the households in Nepal. Given to the limited capacities in the country, they stated the country needs to consider the policy of "poor people prior". Therefore, households that were in the high vulnerability pattern should be considered prior.

\subsection{Compatibility of pastoralists with livelihood vulnerability patterns through adopting appropriate adaptation strategies}

As the results show, 4 adaptation strategies in the form of herd size, nutrition, health, and fodder have been adopted by more than $50 \%$ of pastoral households. The herd size strategy has been adopted by pastoralists in 16 livelihood vulnerability patterns. Only in the livelihood vulnerability pattern 15 , pastoralists were able to reduce their livelihood vulnerability by reducing their herd size. In fact, diversifying activities along with reducing the herd size has led to a reduction in dependence of pastoralists' revenue on rangelands. The nutritional strategy to reduce nutrition dependence on traditional livelihood and the health strategy to follow health recommendations have been adopted by pastoral households in more than 15 livelihood vulnerability patterns. Therefore, none of the patterns were vulnerable in terms of nutrition sensitivity and health sensitivity. While the fodder strategy has been adopted by pastoralists in 9 livelihood vulnerability patterns, it was only able to reduce the LVI-IPCC score (9.69) in the 4th pattern compared to the corresponding score of Eghlid (11.51). In addition to the mentioned adaptation strategies, 3 adaptation strategies of evacuation, credit, and skill in combination with others were appropriate to reduce livelihood vulnerability. Pastoralists in the 4th, 14th, 15th, and 21 st 
patterns were compatible with livelihood vulnerability sub-components through adopting the appropriate set of adaptation strategies. Considering that pastoralists took appropriate decisions to adopt the adaptation strategies in only 4 livelihood vulnerability patterns, the compatibility of pastoralists with the extracted patterns is low. Other studies on the adaptation of farmers and pastoralists to climate change in Iran have obtained similar results. In Hamadan province, Jamshidi et al. (2020) claimed that most farmers have adopted three adaptation strategies, such as applying new irrigation methods, shifting to drought tolerant varieties, and diversifying household income resources to adapt to climate change. In Fars province, based on a study by Karimi et al. (2018), a large number of livestock producers used three adaptation strategies e.g., rotational grazing, raising mixed herd, and purchasing fodder. In this context, Keshavarz et al.'s (2017) study showed that farmers followed the adaptation strategies of farm management, financial management, and income diversification. Accordingly, it can be concluded that the diversification of income-generating activities and non-reliance on traditional livelihoods are effective measures taken in the face of climate variability and change.

\section{Conclusion}

To address the first research question, it should be mentioned that pastoralists have high livelihood vulnerability in terms of risk exposure in the northern Fars province. Their revenue that has basically gained from traditional pastoralism has reduced severely due to climate change and degraded rangelands. In addition, the ecological sensitivity of rangelands to climate change is high in Eghlid and Shiraz. The ecology of those rangelands has been degraded by natural phenomena in recent years. Also, the low adaptive capacity in terms of cash and skill has increased the livelihood vulnerability of Iranian pastoralists. To address the second research question, it should be noted that 27 livelihood vulnerability patterns were detected with respect to the sub-components of exposure, sensitivity, and adaptation and patterns indicate the relationships among the sub-components. Those relationships are mainly distinguished among 5 sub-components of climate exposure, rangeland exposure, ecological sensitivity, time adaptation, budget adaptation, and skill adaptation. The third research question should be addressed through comparing the vulnerability score of each pattern with related county; pastoralists have adopted an appropriate set of adaptation strategies to reduce their livelihood vulnerability in only 4 livelihood vulnerability patterns. Therefore, pastoralists are compatible with livelihood vulnerability patterns at the low level. In fact, the livelihood vulnerability score in each pattern is high compared to the corresponding score of the related county. This means that pastoralists in each vulnerability pattern (excluding 4 patterns) have not adopted an appropriate set of adaptation strategies.

Lack of attention to reduce the vulnerability of Iranian pastoralists to climate change leads to instability in their livelihoods. In line with the mentioned implication, incorrect policy making by authorities and imperfect adoption of adaptation strategies by Iranian pastoralists not only does not reduce the livelihood vulnerability of pastoralists to climate change, but also increases it. The results of the current study can assist pastoralists to adopt an appropriate set of adaptation strategies in the northern Fars province. Thus, the adoption of the diversification strategy in the form of diversifying income earning activities is recommended to pastoralists who were exposed to climate change and degraded rangelands. 
It is also suggested to improve the quality of rangelands by adopting the herd size strategy in the form of reducing herd size, the fodder strategy in the form of feeding the herd with purchased fodder, and the evacuation strategy in the form of evacuating natural rangelands. Increasing the adaptive capacity is recommended for pastoralists who were vulnerable due to adaptation, in 2 ways: firstly, granting the production credits to start complementary activities, and secondly, holding various skill courses for training those pastoralists.

Almost none of the pastoralists has adopted some adaptation strategies, such as herd insurance, substitution of goats instead of sheep, more favorable rangeland migration, and rangelands restoration. Future studies can examine why pastoralists are reluctant to adopt some adaptation strategies, or how policy makers can encourage pastoralists to change the composition of their herd and migrate to more favorable and safer rangelands. In this regard, untimely pastoralists' migration can be identified as a factor for degrading the rangeland quality. To direct future studies in the context of rangeland quality management, it is also important to evaluate the exact time of herd entry on various rangelands and the length of the grazing period.

\section{References}

Adu, D.T., Kuwornu, J.K.M., Anim-Somuah, H., Sasaki, N. (2018). Application of livelihood vulnerability index in assessing smallholder maize farming households' vulnerability to climate change in BrongAhafo region of Ghana. Kasetsart Journal of Social Sciences, 39(1), 22-32.

doi:10.1016/j.kjss.2017.06.009

Agricultural Jihad Organization. (2018). Agricultural Yearbook of Fars province.

Amos, E., Akpan, U., Ogunjobi, K. (2014). Households' perception and livelihood vulnerability to climate change in a coastal area of Akwa Ibom State, Nigeria. Environment, Development and Sustainability, 17(4), 887-908. doi:10.1007/s10668-014-9580-3

Ashok, K.R., Sasikala, C. (2012). Farmers vulnerability to rainfall variability and technology adoption in rain-fed tank irrigated agriculture. Agricultural Economics Research Review, 25(2), 267-278.

Biazin, B., Sterk, G. (2013). Drought vulnerability drives land-use and land cover changes in the Rift Valley dry lands of Ethiopia. Agriculture, Ecosystems and Environment, 164, 100-113.

doi:10.1016/j.agee.2012.09.012

Bogaerts, M., Cirhigiri, L., Robinson, I., Rodkin, M., Hajjar, R., Costa Junior, C., Newton, P. (2017). Climate change mitigation through intensified pasture management: Estimating greenhouse gas emissions on cattle farms in the Brazilian Amazon. Journal of Cleaner Production, 162, 1539-1550.

doi:10.1016/j.jclepro.2017.06.130

Carolan, M. (2019). Filtering perceptions of climate change and biotechnology: values and views among Colorado farmers and ranchers. Climatic Change, 159, 121-139. doi:10.1007/s10584-019-02625-0 
Chatrchyan, A.M., Erlebacher, R.C., Chaopricha, N.T., Chan, J., Tobin, D., Allred, S.B. (2017). United States agricultural stakeholder views and decisions on climate change. Wiley Interdisciplinary Reviews: Climate Change, 8(5), e469. doi:10.1002/wcc.469

Dang, H.L., Li, E., Nuberg, I., Bruwer, J. (2014). Understanding farmers' adaptation intention to climate change: A structural equation modelling study in the Mekong Delta, Vietnam. Environmental Science \& Policy, 41, 11-22. doi:10.1016/j.envsci.2014.04.002

Dendir, Z., Simane, B. (2019). Livelihood vulnerability to climate variability and change in different agroecological zones of Gurage Administrative Zone, Ethiopia. Progress in Disaster Science, 3, 100035. doi:10.1016/j.pdisas.2019.100035

Endalew, H.A., Sen, S. (2020). Effects of climate shocks on Ethiopian rural households: an integrated livelihood vulnerability approach. Journal of Environmental Planning and Management, 1-33. doi:10.1080/09640568.2020.1764840

Gerlitz, J.-Y., Macchi, M., Brooks, N., Pandey, R., Banerjee, S., Jha, S.K. (2016). The Multidimensional Livelihood Vulnerability Index - an instrument to measure livelihood vulnerability to change in the Hindu Kush Himalayas. Climate and Development, 9(2), 124-140. doi:10.1080/17565529.2016.1145099

Grothmann, T., Patt, A. (2005). Adaptive capacity and human cognition: The process of individual adaptation to climate change. Global Environmental Change, 15(3), 199-213.

doi:10.1016/j.gloenvcha.2005.01.002

Habibyian, S.M., Barani, H. (2019). Prioritizing of affecting factors on grazing management using AHP method in nomad's rangelands at Fars Province. Iranian Journal of Range and Desert Research, 26(4), 809-822.

Hahn, M.B., Riederer, A.M., Foster, S.O. (2009). The Livelihood Vulnerability Index: A pragmatic approach to assessing risks from climate variability and change-A case study in Mozambique. Global Environmental Change, 19(1), 74-88. doi:10.1016/j.gloenvcha.2008.11.002

Hair, J.F., Anderson, R.E., Babin, B.J. and Black, W.C. (2010). Multivariate data analysis: A global perspective: Pearson Upper Saddle River.

Hamidi, A.R., Zeng, Z., Marwat, A.K. (2020). Household vulnerability to floods and cyclones in Khyber Pakhtunkhwa, Pakistan. International Journal of Disaster Risk Reduction, 46, 101496.

doi:10.1016/j.ijdrr.2020.101496

Jamshidi, O., Asadi, A., Kalantari, K., Azadi, H., Scheffran, J. (2019). Vulnerability to climate change of smallholder farmers in the Hamadan province, Iran. Climate Risk Management, 23, 146-159.

doi:10.1016/j.crm.2018.06.002 
Jamshidi, O., Asadi, A., Kalantari, K., Movahhed Moghaddam, S., Dadrass Javan, F., Azadi, H., Van Passel, S., Witlox, F. (2020). Adaptive capacity of smallholder farmers toward climate change: evidence from Hamadan province in Iran. Climate and Development. doi:10.1080/17565529.2019.1710097

Karimi, V., Karami, E., Keshavarz, M. (2018). Vulnerability and Adaptation of Livestock Producers to Climate Variability and Change. Rangeland Ecology \& Management, 71(2), 175-184.

doi:10.1016/j.rama.2017.09.006

Keshavarz, M., Karami, E. (2016). Farmers' pro-environmental behavior under drought: Application of protection motivation theory. Journal of Arid Environments, 127, 128-136.

doi:10.1016/j.jaridenv.2015.11.010

Keshavarz, M., Maleksaeidi, H., Karami, E. (2017). Livelihood vulnerability to drought: A case of rural Iran. International Journal of Disaster Risk Reduction, 21, 223-230. doi:10.1016/j.ijdrr.2016.12.012

Khodahami, G., Zandi Esfahan, E. (2015). Investigation on the allowable use of range species (Case study: Sepidan semi-steppe rangelands, Fars, Iran). Journal of Biodiversity and Environmental Sciences (JBES), 6(3), 141-145.

Kogo, B.K., Kumar, L., Koech, R. (2020). Climate change and variability in Kenya: a review of impacts on agriculture and food security. Environment, Development and Sustainability. doi:10.1007/s10668-02000589-1

Kok, M., Lüdeke, M., Lucas, P., Sterzel, T., Walther, C., Janssen, P., Sietz, D., de Soysa, I. (2015). A new method for analysing socio-ecological patterns of vulnerability. Regional Environmental Change, 16(1), 229-243. doi:10.1007/s10113-014-0746-1

McMillen, H., Ticktin, T., Springer, H.K. (2017). The future is behind us: Traditional ecological knowledge and resilience over time on Hawai'i Island. Regional Environmental Change, 17, 579-592. doi:10.1007/s10113-016-1032-1

Meteorological Organization, (2020). Meteorological Yearbook of Fars province.

Morzaria-Luna, H.N., Turk-Boyer, P., Moreno-Baez, M. (2014). Social indicators of vulnerability for fishing communities in the Northern Gulf of California, Mexico: Implications for climate change. Marine Policy, 45, 182-193. doi:10.1016/j.marpol.2013.10.013

Nabua, W., Bureros, N., Aquino, J. (2010). Estimation the health and economic vulnerabilities of the indigenous people (IP) in zamboanga del norte to the effects of climate change. International Scientific Research Journal, 2(4), 1749-2094.

Nandintsetseg, B., Shinoda, M., Erdenetsetseg, B. (2018). Contributions of multiple climate hazards and overgrazing to the 2009/2010 winter disaster in Mongolia. Natural Hazards, 92, 109-126. doi:10.1007/s11069-017-2954-8 
Neibergs, J.S., Hudson, T.D., Kruger, C.E., Hamel-Rieken, K. (2018). Estimating climate change effects on grazing management and beef cattle production in the Pacific Northwest. Climatic Change, 146(1-2), 517. doi:10.1007/s10584-017-2014-0

Omerkhil, N., Chand, T., Valente, D., Alatalo, J.M., Pandey, R. (2020). Climate change vulnerability and adaptation strategies for smallholder farmers in Yangi Qala District, Takhar, Afghanistan. Ecological Indicators, 110, 105863. doi:10.1016/j.ecolind.2019.105863

Omidvar, E., Mohtasham Nia, S. (2015). Rangelands suitability for sheep grazing in semi-steppic rangelands of Tornas Eghlid Fars Province by GIS. Renewable Natural Resources Research, 6(2), 65-78.

Ojo, T.O. and Baiyegunhi, L.J.S., (2020). Impact of climate change adaptation strategies on rice productivity in South-west, Nigeria: An endogeneity corrected stochastic frontier model. Science of The Total Environment, 745, p.141151.

Ojo, T.O., Adetoro, A.A., Ogundeji, A.A. and Belle, J.A., (2021). Quantifying the determinants of climate change adaptation strategies and farmers' access to credit in South Africa. Science of The Total Environment, p.148499.

Pandey, R., Bardsley, D.K. (2015). Social-ecological vulnerability to climate change in the Nepali Himalaya. Applied Geography, 64, 74-86. doi:10.1016/j.apgeog.2015.09.008

Panthi, J., Aryal, S., Dahal, P., Bhandari, P., Krakauer, N.Y., Pandey, V.P. (2015). Livelihood vulnerability approach to assessing climate change impacts on mixed agro-livestock smallholders around the Gandaki River Basin in Nepal. Regional Environmental Change, 16(4), 1121-1132. doi:10.1007/s10113-015-0833y

Rashid, R.A.A., Nohuddin, P.N.E., Zainol, Z. (2017). Association Rule Mining Using Time Series Data for Malaysia Climate Variability Prediction. In: Badioze Zaman H. et al. (eds) Advances in Visual Informatics. IVIC 2017. Lecture Notes in Computer Science, vol 10645. Springer, Cham. doi:10.1007/978-3-319-700106_12

Scheaffer, R.L., Mendenhall-III, W., Lyman-Ott, R., Gerow, K. (2012). Elementary Survey Sampling. (7th ed.). Boston, USA.

Setten, G., Lein, H. (2019). "We draw on what we know anyway": The meaning and role of local knowledge in natural hazard management. International Journal of Disaster Risk Reduction, 38, 101184. doi:10.1016/j.ijdrr.2019.101184

Sietz, D., Mamani Choque, S.E., Lüdeke, M.K.B. (2011). Typical patterns of smallholder vulnerability to weather extremes with regard to food security in the Peruvian Altiplano. Regional Environmental Change, 12(3), 489-505. doi:10.1007/s10113-011-0246-5

Statistical Center of Iran, (2016). Statistical Yearbook of Fars province. 
Thathsarani, U.S., Gunaratne, L.H.P. (2018). Constructing and Index to Measure the Adaptive Capacity to Climate Change in Sri Lanka. Procedia Engineering, 212, 278-285. doi:10.1016/j.proeng.2018.01.036

Toufique, K.A., Islam, A. (2014). Assessing risks from climate variability and change for disaster-prone zones in Bangladesh. International Journal of Disaster Risk Reduction, 10, 236-249.

doi:10.1016/j.ijdrr.2014.08.008

Wüst-Galley, C., Volk, M., Bassin, S. (2020). Interaction of climate change and nitrogen deposition on subalpine pastures. Journal of Vegetation Science, doi:org/10.1111/jvs.12946

Zhang, Q., Cui, F., Dai, L., Feng, B., Lu, Y., Tang, H. (2019). Pastoralists' perception of and adaptation strategies for climate change: associations with observed climate variability. Natural Hazards, 96, 13871412. doi:10.1007/s11069-019-03620-5

Zorom, M., Barbier, B., Mertz, O., Servat, E. (2013). Diversification and adaptation strategies to climate variability: A farm typology for the Sahel. Agricultural Systems, 116, 7-15.

doi:10.1016/j.agsy.2012.11.004

\section{Tables}

\section{Table 1}

The main components, and sub-components considered in the questionnaire 


\begin{tabular}{|c|c|c|}
\hline $\begin{array}{l}\text { Main } \\
\text { component }\end{array}$ & $\begin{array}{l}\text { Sub- } \\
\text { component }\end{array}$ & Explanation \\
\hline \multirow[t]{2}{*}{$\begin{array}{l}\text { Risk } \\
\text { exposure }\end{array}$} & $\begin{array}{l}\text { Climate } \\
\text { exposure }\end{array}$ & $\begin{array}{l}\text { To what extent pastoralists' revenue has been affected by climate } \\
\text { change, including drought, frost, and untimely floods }\end{array}$ \\
\hline & $\begin{array}{l}\text { Rangeland } \\
\text { exposure }\end{array}$ & $\begin{array}{l}\text { To what extent pastoralists' revenue has been affected by degraded } \\
\text { rangelands }\end{array}$ \\
\hline \multirow[t]{3}{*}{ Sensitivity } & $\begin{array}{l}\text { Health } \\
\text { sensitivity }\end{array}$ & $\begin{array}{l}\text { To what extent households' health has been affected by climatic } \\
\text { conditions }\end{array}$ \\
\hline & $\begin{array}{l}\text { Nutrition } \\
\text { sensitivity }\end{array}$ & $\begin{array}{l}\text { To what extent households' nutrition has been affected by traditional } \\
\text { pastoralist }\end{array}$ \\
\hline & $\begin{array}{l}\text { Ecology } \\
\text { sensitivity }\end{array}$ & $\begin{array}{l}\text { To what extent rangelands' ecology has been affected by natural } \\
\text { phenomena }\end{array}$ \\
\hline \multirow[t]{3}{*}{$\begin{array}{l}\text { Adaptive } \\
\text { capacity }\end{array}$} & $\begin{array}{l}\text { Time } \\
\text { adaptation }\end{array}$ & $\begin{array}{l}\text { To what extent households have had time to engage in other income } \\
\text { earning activities }\end{array}$ \\
\hline & $\begin{array}{l}\text { Budget } \\
\text { adaptation }\end{array}$ & $\begin{array}{l}\text { To what extent households have had budget to engage in other } \\
\text { income earning activities }\end{array}$ \\
\hline & $\begin{array}{l}\text { Skill } \\
\text { adaptation }\end{array}$ & $\begin{array}{l}\text { To what extent households have had skills to engage in other } \\
\text { income earning activities }\end{array}$ \\
\hline \multirow[t]{12}{*}{$\begin{array}{l}\text { Adaptation } \\
\text { strategies }\end{array}$} & Diversification & $\begin{array}{l}\text { To what extent households have diversified the income earning } \\
\text { activities }\end{array}$ \\
\hline & Herd size & To what extent pastoralists have reduced its herd size \\
\hline & Fodder & To what extent pastoralists have fed its herd with fodder \\
\hline & Insurance & To what extent pastoralists have insured its herd \\
\hline & Substitution & To what extent pastoralists have substituted goats instead of sheep \\
\hline & Migration & $\begin{array}{l}\text { To what extent pastoralists have migrated to more favorable } \\
\text { rangelands }\end{array}$ \\
\hline & Evacuation & To what extent pastoralists have evacuated its rangelands \\
\hline & Restoration & To what extent pastoralists have restored its rangelands \\
\hline & Health & $\begin{array}{l}\text { To what extent households have followed the health } \\
\text { recommendations }\end{array}$ \\
\hline & Nutrition & $\begin{array}{l}\text { To what extent households have reduced its nutrition dependence on } \\
\text { traditional livelihood }\end{array}$ \\
\hline & Credit & $\begin{array}{l}\text { To what extent households have received credits from banks and } \\
\text { financial institutions }\end{array}$ \\
\hline & Skill & $\begin{array}{l}\text { To what extent households have participated in skill course of } \\
\text { learning handicraft, apiculture, and fish farming }\end{array}$ \\
\hline & indings & \\
\hline
\end{tabular}




\section{Table 2}

Weighing the sub-components using the principal component analysis

\begin{tabular}{|llll|}
\hline Main component & Sub-component & Weight & Proportion of explained variation \\
\hline Risk exposure & Climate exposure & 0.94 & 0.71 \\
\hline Sensitivity & Rangeland exposure & 0.06 & \\
\hline & Health sensitivity & 0.38 & 0.57 \\
\hline Nutrition sensitivity & 0.35 & \\
\hline Adaptive capacity & Ecology sensitivity & 0.27 & \\
\hline & Time adaptation & 0.60 & 0.63 \\
\hline & Budget adaptation & 0.22 & \\
\hline Skill adaptation & 0.18 & \\
\hline
\end{tabular}

\section{Table 3}

Data understanding in terms of acceptable range, missing data, outliers, and data consistency 


\begin{tabular}{|lllll|}
\hline Sub-component & $\begin{array}{l}\text { Acceptable } \\
\text { range }\end{array}$ & $\begin{array}{l}\text { Missing } \\
\text { data }\end{array}$ & Outlier & Data consistency \\
\hline $\begin{array}{l}\text { Climate } \\
\text { exposure }\end{array}$ & {$[1,7]$} & 0 & 0 & $\begin{array}{l}\text { Higher value indicates more livelihood } \\
\text { vulnerability }\end{array}$ \\
\hline $\begin{array}{l}\text { Rangeland } \\
\text { exposure }\end{array}$ & {$[1,7]$} & 0 & 0 & $\begin{array}{l}\text { Higher value indicates more livelihood } \\
\text { vulnerability }\end{array}$ \\
$\begin{array}{l}\text { Health } \\
\text { sensitivity }\end{array}$ & {$[1,7]$} & 0 & 0 & $\begin{array}{l}\text { Higher value indicates more livelihood } \\
\text { vulnerability }\end{array}$ \\
\hline $\begin{array}{l}\text { Nutrition } \\
\text { sensitivity }\end{array}$ & {$[1,7]$} & 0 & 0 & $\begin{array}{l}\text { Higher value indicates more livelihood } \\
\text { vulnerability }\end{array}$ \\
\hline $\begin{array}{l}\text { Ecology } \\
\text { sensitivity }\end{array}$ & {$[1,7]$} & 0 & 0 & $\begin{array}{l}\text { Higher value indicates more livelihood } \\
\text { vulnerability }\end{array}$ \\
\hline $\begin{array}{l}\text { Time } \\
\text { adaptation }\end{array}$ & {$[1,7]$} & 0 & 0 & $\begin{array}{l}\text { Higher value indicates less livelihood } \\
\text { vulnerability }\end{array}$ \\
\hline $\begin{array}{l}\text { Budget } \\
\text { adaptation }\end{array}$ & {$[1,7]$} & 0 & 0 & $\begin{array}{l}\text { Higher value indicates less livelihood } \\
\text { vulnerability }\end{array}$ \\
\hline Skill adaptation & {$[1,7]$} & 0 & 0 & $\begin{array}{l}\text { Higher value indicates less livelihood } \\
\text { vulnerability }\end{array}$ \\
\hline Source: Study findings & & & \\
\hline
\end{tabular}

\section{Table 4}

Livelihood vulnerability scores 


\begin{tabular}{|lllll|}
\hline Main component & Sub-component & Eghlid & Sepidan & Shiraz \\
\hline Risk exposure & & 6.92 & 5.65 & 5.60 \\
& Climate exposure & 6.92 & 5.64 & 5.60 \\
\hline Sensitivity & Rangeland exposure & 6.90 & 5.75 & 5.55 \\
& & 2.45 & 1.83 & 2.26 \\
\hline & Health sensitivity & 1.33 & 1.19 & 1.13 \\
\hline Adaptive capacity & Nutrition sensitivity & 1.92 & 2.68 & 2.17 \\
& Ecology sensitivity & 4.70 & 1.64 & 3.97 \\
\hline & Time adaptation & 2.74 & 1.81 & 2.81 \\
\hline BVI-IPCC score & Skill adaptation & 1.59 & 1.11 & 1.18 \\
\hline Source: Study findings & 11.51 & 7.56 & 7.75 \\
\hline
\end{tabular}

Table 5

Compatibility of adaptation strategies adopted by pastoralists with livelihood vulnerability patterns 


\begin{tabular}{|c|c|c|c|c|}
\hline No & County & Livelihood vulnerability pattern & $\begin{array}{l}\text { Adaptation } \\
\text { strategies }\end{array}$ & $\begin{array}{l}\text { LVI- } \\
\text { IPCC } \\
\text { score }\end{array}$ \\
\hline 1 & Eghlid & (Climate exposure, Rangeland exposure) & $\begin{array}{l}\text { Health, Nutrition, } \\
\text { Herd size }\end{array}$ & 11.61 \\
\hline 2 & Eghlid & (Climate exposure, Skill adaptation) & $\begin{array}{l}\text { Health, Herd size, } \\
\text { Credit }\end{array}$ & 11.69 \\
\hline 3 & Eghlid & (Rangeland exposure, Budget adaptation) & $\begin{array}{l}\text { Nutrition, Herd } \\
\text { size, Skill }\end{array}$ & 11.85 \\
\hline 4 & Eghlid & (Rangeland exposure, Skill adaptation) & $\begin{array}{l}\text { Diversification, } \\
\text { Fodder, Skill }\end{array}$ & 9.69 \\
\hline 5 & Eghlid & $\begin{array}{l}\text { (Climate exposure, Rangeland exposure, Skill } \\
\text { adaptation) }\end{array}$ & $\begin{array}{l}\text { Health, Nutrition, } \\
\text { Credit }\end{array}$ & 11.78 \\
\hline 6 & Eghlid & $\begin{array}{l}\text { (Rangeland exposure, Budget adaptation, Skill } \\
\text { adaptation) }\end{array}$ & $\begin{array}{l}\text { Health, Nutrition, } \\
\text { Diversification }\end{array}$ & 10.89 \\
\hline 7 & Eghlid & $\begin{array}{l}\text { (Climate exposure, Rangeland exposure, Time } \\
\text { adaptation, Budget adaptation) }\end{array}$ & $\begin{array}{l}\text { Health, Nutrition, } \\
\text { Herd size }\end{array}$ & 12.48 \\
\hline 8 & Eghlid & $\begin{array}{l}\text { (Climate exposure, Rangeland exposure, Time } \\
\text { adaptation, Skill adaptation) }\end{array}$ & $\begin{array}{l}\text { Health, Nutrition, } \\
\text { Insurance }\end{array}$ & 12.66 \\
\hline 9 & Eghlid & $\begin{array}{l}\text { (Climate exposure, Rangeland exposure, Ecology } \\
\text { sensitivity, Time adaptation, Budget adaptation) }\end{array}$ & $\begin{array}{l}\text { Health, Nutrition, } \\
\text { Fodder }\end{array}$ & 14.51 \\
\hline 10 & Eghlid & $\begin{array}{l}\text { (Rangeland exposure, Ecology sensitivity, Time } \\
\text { adaptation, Budget adaptation, Skill adaptation) }\end{array}$ & $\begin{array}{l}\text { Health, Nutrition, } \\
\text { Herd size }\end{array}$ & 14.59 \\
\hline 11 & Sepidan & (Climate exposure, Rangeland exposure) & $\begin{array}{l}\text { Herd size, } \\
\text { Nutrition, Fodder }\end{array}$ & 7.73 \\
\hline 12 & Sepidan & (Climate exposure, Budget adaptation) & $\begin{array}{l}\text { Herd size, } \\
\text { Nutrition, Health }\end{array}$ & 7.95 \\
\hline 13 & Sepidan & (Climate exposure, Skill adaptation) & $\begin{array}{l}\text { Nutrition, Health, } \\
\text { Fodder }\end{array}$ & 8.43 \\
\hline 14 & Sepidan & (Rangeland exposure, Budget adaptation) & $\begin{array}{l}\text { Diversification, } \\
\text { Evacuation, } \\
\text { Credit }\end{array}$ & 5.68 \\
\hline 15 & Sepidan & (Rangeland exposure, Skill adaptation) & $\begin{array}{l}\text { Herd size, } \\
\text { Diversification, } \\
\text { Skill }\end{array}$ & 4.68 \\
\hline 16 & Sepidan & $\begin{array}{l}\text { (Rangeland exposure, Time adaptation, Budget } \\
\text { adaptation) }\end{array}$ & $\begin{array}{l}\text { Nutrition, Herd } \\
\text { size, Health }\end{array}$ & 7.92 \\
\hline 17 & Sepidan & $\begin{array}{l}\text { (Rangeland exposure, Time adaptation, Skill } \\
\text { adaptation) }\end{array}$ & $\begin{array}{l}\text { Nutrition, Herd } \\
\text { size, Fodder }\end{array}$ & 7.12 \\
\hline
\end{tabular}




\begin{tabular}{|c|c|c|c|c|}
\hline No & County & Livelihood vulnerability pattern & $\begin{array}{l}\text { Adaptation } \\
\text { strategies }\end{array}$ & $\begin{array}{l}\text { LVI- } \\
\text { IPCC } \\
\text { score }\end{array}$ \\
\hline 18 & Sepidan & $\begin{array}{l}\text { (Climate exposure, Rangeland exposure, Budget } \\
\text { adaptation) }\end{array}$ & $\begin{array}{l}\text { Health, Nutrition, } \\
\text { Insurance }\end{array}$ & 8.56 \\
\hline 19 & Sepidan & $\begin{array}{l}\text { (Climate exposure, Rangeland exposure, Skill } \\
\text { adaptation) }\end{array}$ & $\begin{array}{l}\text { Herd size, Health, } \\
\text { Fodder }\end{array}$ & 8.14 \\
\hline 20 & Shiraz & (Climate exposure, Rangeland exposure) & $\begin{array}{l}\text { Herd size, } \\
\text { Nutrition, Health }\end{array}$ & 7.88 \\
\hline 21 & Shiraz & (Rangeland exposure, Budget adaptation) & $\begin{array}{l}\text { Evacuation, } \\
\text { Diversification, } \\
\text { Credit }\end{array}$ & 6.01 \\
\hline 22 & Shiraz & (Rangeland exposure, Skill adaptation) & $\begin{array}{l}\text { Nutrition, Fodder, } \\
\text { Health }\end{array}$ & 7.28 \\
\hline 23 & Shiraz & $\begin{array}{l}\text { (Climate exposure, Rangeland exposure, Budget } \\
\text { adaptation) }\end{array}$ & $\begin{array}{l}\text { Herd size, Health, } \\
\text { Skill }\end{array}$ & 8.01 \\
\hline 24 & Shiraz & $\begin{array}{l}\text { (Rangeland exposure, Budget adaptation, Skill } \\
\text { adaptation) }\end{array}$ & $\begin{array}{l}\text { Nutrition, Fodder, } \\
\text { Health }\end{array}$ & 8.21 \\
\hline 25 & Shiraz & $\begin{array}{l}\text { (Rangeland exposure, Time adaptation, Budget } \\
\text { adaptation, Skill adaptation) }\end{array}$ & $\begin{array}{l}\text { Herd size, Health, } \\
\text { Insurance }\end{array}$ & 8.69 \\
\hline 26 & Shiraz & $\begin{array}{l}\text { (Climate exposure, Ecology sensitivity, Time } \\
\text { adaptation, Budget adaptation, Skill adaptation) }\end{array}$ & $\begin{array}{l}\text { Herd size, } \\
\text { Nutrition, Fodder }\end{array}$ & 9.03 \\
\hline 27 & Shiraz & $\begin{array}{l}\text { (Rangeland exposure, Ecology sensitivity, Time } \\
\text { adaptation, Budget adaptation, Skill adaptation) }\end{array}$ & $\begin{array}{l}\text { Nutrition, Herd } \\
\text { size, Health }\end{array}$ & 9.39 \\
\hline
\end{tabular}

Source: Study findings

\section{Figures}



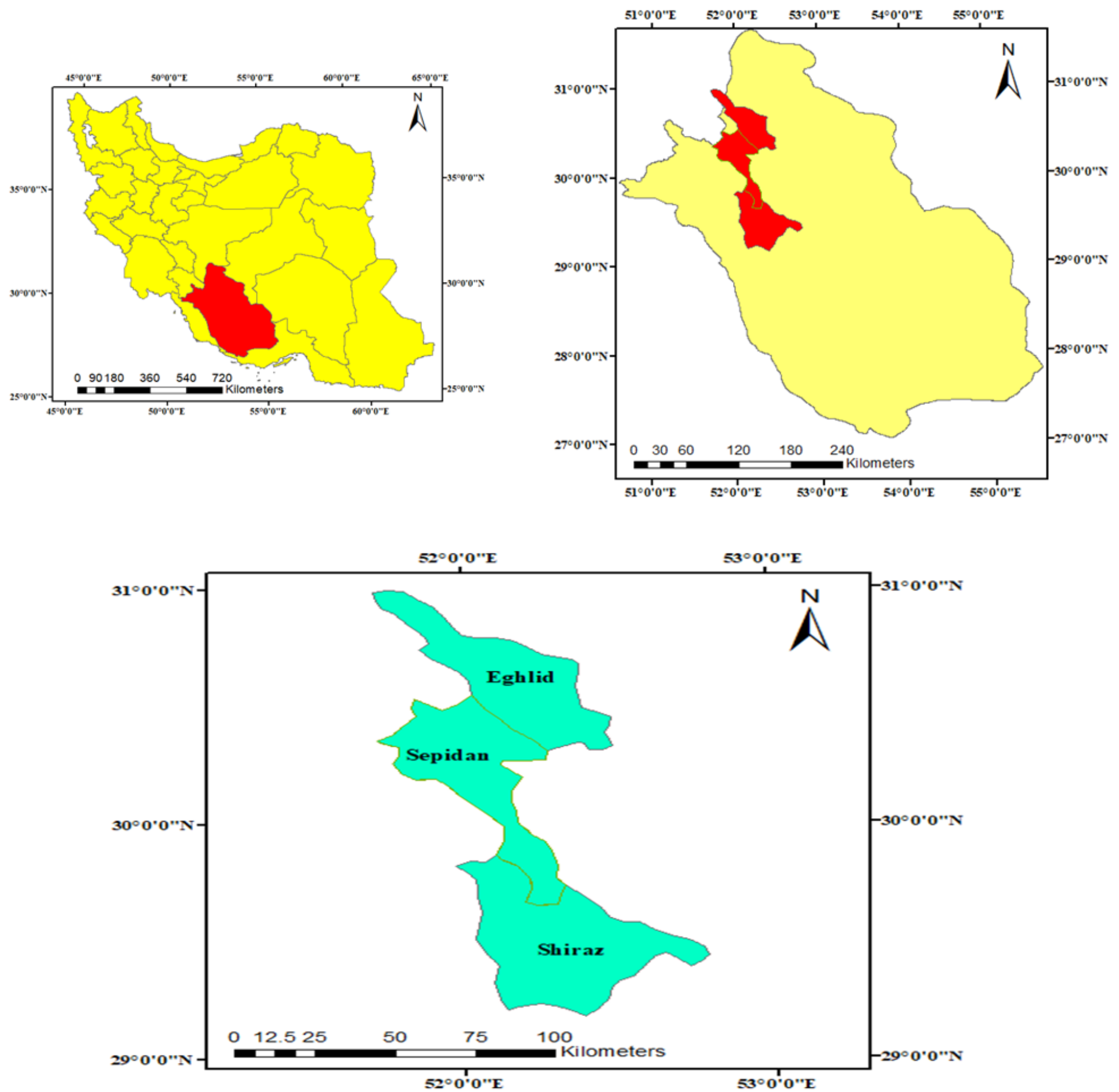

Figure 1

The location of Eghlid, Sepidan, and Shiraz in Fars province, Iran 


\section{Precipitation ( $\mathrm{mm})$}

1000

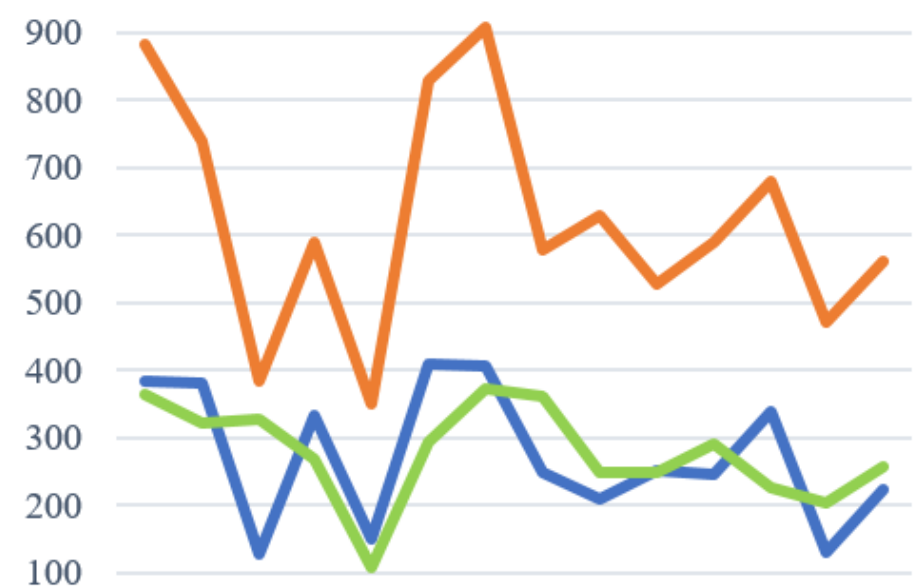

0

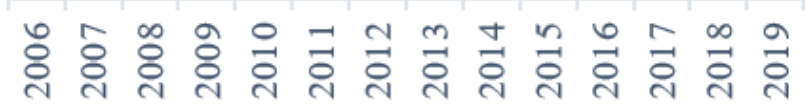

$\longrightarrow$ Eghlid $\longrightarrow$ Sepidan $\rightleftharpoons$ Shiraz

\section{Temperature $\left({ }^{\circ} \mathrm{C}\right)$}

20

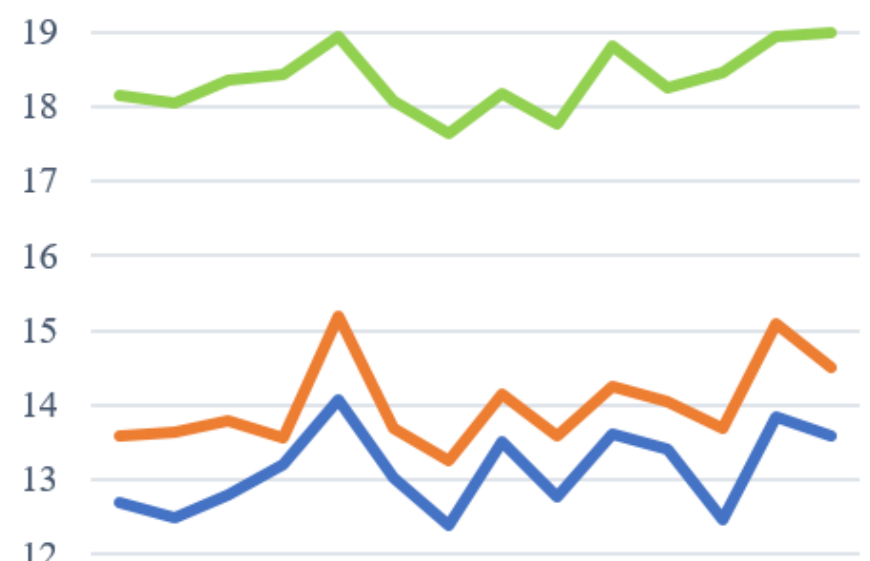

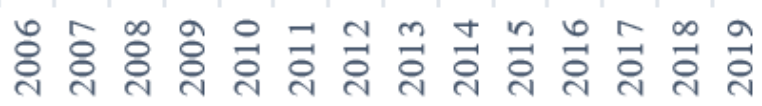

$\longrightarrow$ Eghlid Sepidan Shiraz

Figure 2

Sum of annual precipitation and average temperature of counties

\section{Association rules}

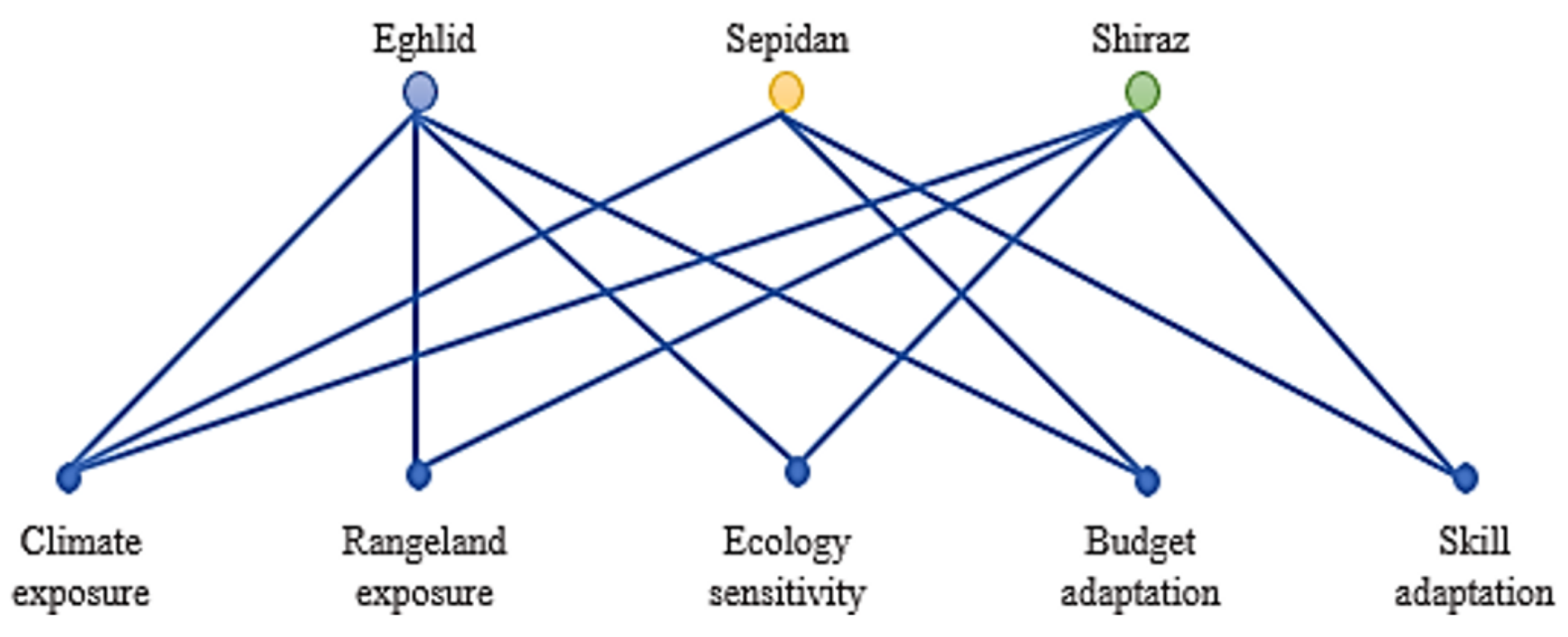

Figure 3

Association rules of livelihood vulnerability sub-components due to 3 counties 


\section{Adaptation strategies}

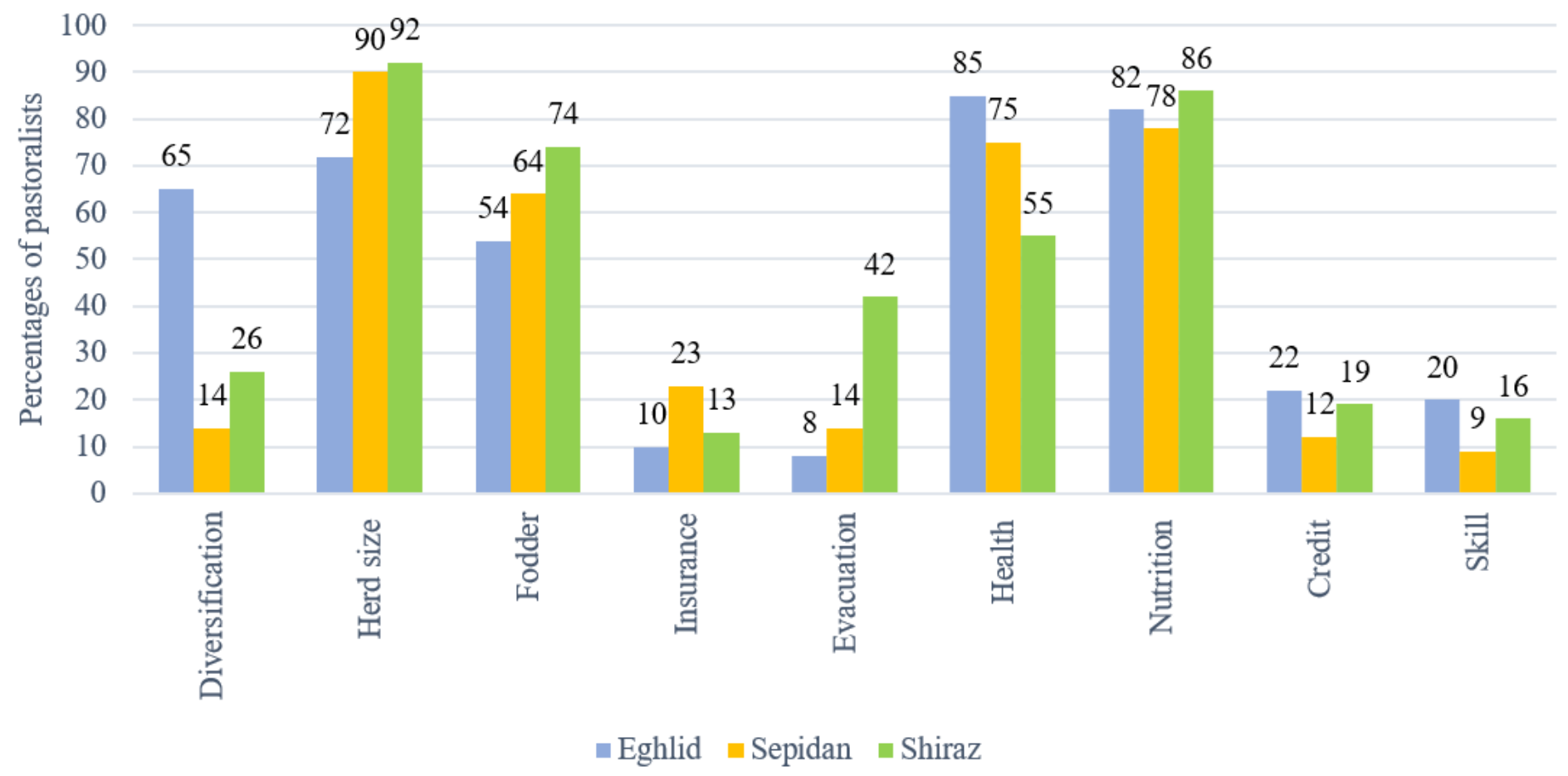

Figure 4

Adaptation strategies adopted by pastoralists 